\title{
MANAJEMEN IMPLEMENTASI KURIKULUM: STRATEGI PENGUATAN IMPLEMENTASI KURIKULUM 2013
}

\author{
Deitje Adolfien Katuuk \\ Fakultas Ilmu Pendidikan Universitas Negeri Manado \\ email:deikatuuk@yahoo.co.id
}

\begin{abstract}
Abstrak: Keberhasilan pengimplementasian kurikulum memerlukan manajemen yang baik. Dalam rangka mengimplementasikan kurikulum 2013, ada beberapa aspek manajemen yang penting sebagai strategi untuk memperkuat pelaksanaannya. Aspek-aspek tersebut meliputi perencanaan implementasi, sumber daya utama dan pendukung, proses pembelajaran di sekolah, dan kegiatan monitoring dan evaluasi. Komponen sekolah terdiri atas guru, kepala sekolah, fasilitas, budaya, lingkungan. Semua komponen tersebut memiliki peran masing-masing dalam penerapan kurikulum baru. Dengan demikian, semua potensi dan sumber daya yang ada perlu dikelola secara menyeluruh dan terpadu agar bermanfaat dalam manajemen implementasi kurikulum. Tersedianya dokumen dan instrumen adalah landasan utama dalam pengimplementasian strategi penerapan kurikulum 2013 di lapangan agar dapat mencapai kualitas yang diharapkan. Selain itu, pemantauan dan evaluasi perlu dikerjakan agar partisipasi semua pihak dapat diperkuat dan untuk mewujudkan manajemen dan strategi implementasi yang lebih baik.
\end{abstract}

\section{Kata Kunci: kurikulum, manajemen, strategi, impelementasi}

\section{MANAGEMENT OF CURRICULUM IMPLEMENTATION: A STRATEGY FOR STRENGTHERNING THE 2013 CURRICULUM IMPLEMENTATION}

\begin{abstract}
The success of the curriculum implementation needed good management. In order to implement the 2013 curriculum, there were some important management aspects as the strategy for strengthening its implementation. Those aspects consisted of the implementation planning, main and supporting resources, the schools' instructional process, and the monitoring and evaluation activity. The school's components included the teachers, principal, facilities, culture, and environment. All those components had their own role in the new curriculum implementation. Therefore, all the existing potentials and resources needed to be managed comprehensively and integratively in order to provide benefits to the curriculum implementation management.The availability of the documents and instruments was the main foundation for the strategy of the 2013 curriculum implementation so that the expected quality could be achieved. In addition, the monitoring and evaluation program needed to be carried out so that the participation of all parties could be strengthened to realize better implementation strategy and management.
\end{abstract}

Keywords: curriculum, management, strategy, implementation

\section{PENDAHULUAN}

Memasuki pertengahan tahun 2013, dunia pendidikan Indonesia dihadapkan pada suatu kebijakan nasional yang sangat penting, yaitu mulai diterapkannya Kurikulum 2013. Kebijakan kurikulum baru menjadi menarik untuk terus dikaji, terutama secara akademik. Hal ini terjadi karena kurikulum merupakan salah satu instrumen penting dalam proses pendidikan, dan selalu mengalami proses pembaharuan seiring de- ngan perkembangan yang terjadi di masyarakat. Oleh sebab itu, pembaharuan kurikulum harus dipandang sebagai suatu tuntutan perubahan. Dinamika perkembangan kurikulum sebagai suatu tuntutan perubahan mengandung implikasi bahwa perubahan kurikulum merupakan sesuatu yang imperatif agar kurikulum yang berlaku tetap memiliki relevansi dengan kebutuhan masyarakat. 
Kebijakan tentang pemberlakukan kurikulum 2013 harus dilihat dalam konteks tuntutan perubahan yang harus dihadapi oleh bangsa Indonesia, baik saat ini maupun untuk masa yang akan datang. Pada setiap kesempatan sosialisasi Kurikulum 2013, Menteri Pendidikan dan Kebudayaan RI mengemukakan bahwa terdapat berbagai rasional pentingnya Kurikulum 2013. Pertama, penyiapan Generasi Emas Indonesia dalam rangka seratus tahun Indonesia merdeka. Hal ini berkaitan dengan struktur penduduk Indonesia 2010, penduduk usia 0-9 dan 10-19 menempati porsi yang sangat besar, yaitu usia 0-9 berjumlah 45.93 juta, dan usia 10-19 tahun berjumlah 43.55 juta (Nuh, 2013).

Memasuki seratus tahun Indonesia merdeka (2045), penduduk di kedua usia ini sudah akan berusia 35-44 tahun dan 45-54 tahun. Kelompok ini merupakan golongan penduduk yang berada pada usia produktif dan merupakan calon-calon pemimpin. Karena merupakan kelompok usia strategis, mereka harus dipersiapkan sedini mungkin.

Kedua, penyiapan kesanggupan Indonesia untuk menghadapi masalah-masalah yang terkait dengan globalisasi: WTO, ASEAN Economic Community, APEC, CAFTA; masalah lingkungan hidup; kemajuan teknologi informasi; konvergensi ilmu dan teknologi; ekonomi berbasis pengetahuan; kebangkitan industri kreatif dan budaya; pergeseran kekuatan ekonomi dunia; mutu, investasi dan transformasi pada sektor pendidikan. Tuntutan perkembangan global melahirkan kebutuhan akan generasi yang memiliki kemampuan kompetitif dan kemampuan menyelesaikan tantangan-tantangan sulit pada masa depan.

Di samping kedua alasan objektif tersebut di atas, dua isu strategis pendidikan perlunya perubahan kurikulum saat ini, yaitu mutu pendidikan khususnya daya saing pendidikan dan pembentukan karakter bangsa. Masalah daya saing pendidikan, sebagaimana dilaporkan oleh The Global Competitiveness Report 20112012, menunjukkan bahwa daya saing pendidikan Indonesia pada tahun 2012 sangat memrihatinkan. Indonesia masih berada pada posisi 46 dari 142 negara yang dinilai, turun dua tingkat dari posisi 44 di tahun 2011. Gambaran posisi daya saing Indonesia di antara negara-negara ASEAN pun belum cukup memuaskan (Tabel 1).

Tabel 1. Posisi Daya Saing Indonesia di antara Negara-negara Asean

\begin{tabular}{lccc}
\hline \multicolumn{1}{c}{ Negara } & 2011 & 2012 & Score \\
\hline Singapore & 2 & 2 & 5.63 \\
Malaysia & 21 & 21 & 5.08 \\
Brunei Darusalam & 28 & 28 & 4.78 \\
Thailand & 39 & 39 & 4.52 \\
Indonesia & $\mathbf{4 4}$ & $\mathbf{4 6}$ & $\mathbf{4 . 3 8}$ \\
Philipines & 75 & 75 & 4.08 \\
\hline
\end{tabular}

Sumber: Klaus Schwab, The Global Competitiveness Report 2011-12, World Economic Forum: http://www3.weforum. org/ docs / WEF (Diakses 26 September 2012)

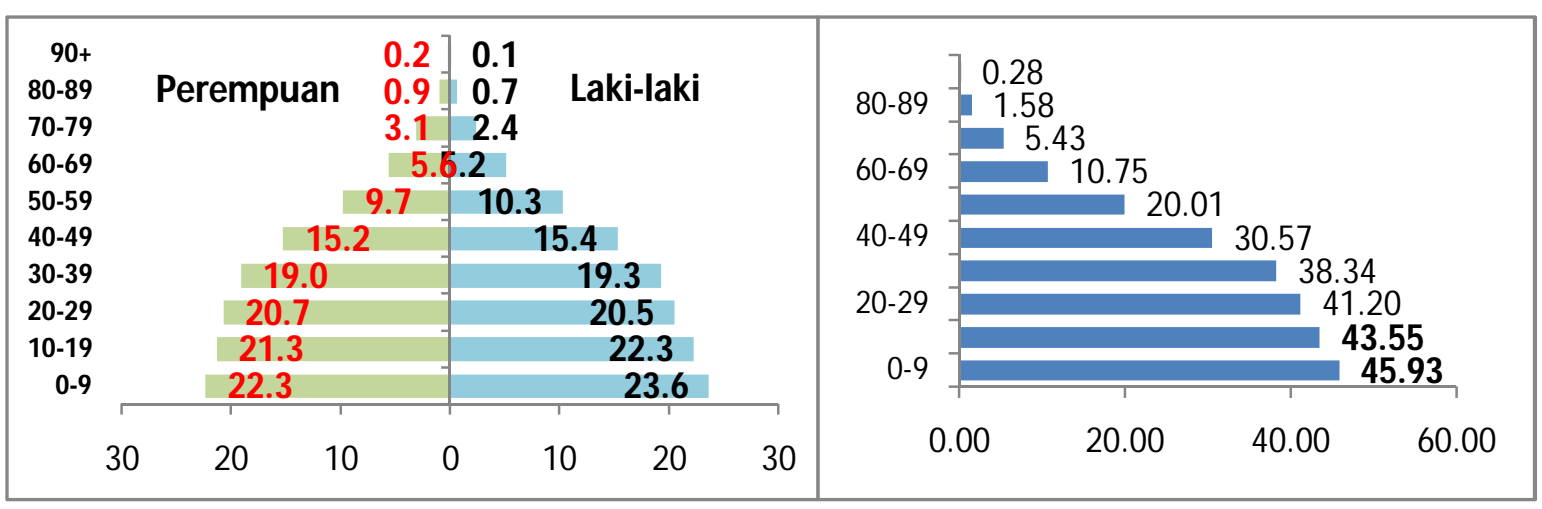

Grafik 1. Struktur Penduduk Indonesia Tahun 2010 
Isu strategis berikutnya adalah masalah pembentukan karakter bangsa. Beberapa masalah penting pembangunan karakter bangsa dan negara Indonesia saat ini dan ke depan antara lain adalah disorientasi dan belum dihayatinya nilai-nilai Pancasila, bergesernya nilai-nilai etika dalam kehidupan berbangsa dan bernegara, memudarnya kesadaran terhadap nilainilai budaya bangsa, ancaman disintegrasi bangsa, dan melemahnya kemandirian bangsa (Winataputra, 2010:9). Hasil survei Transperancy International Indonesia yang diumumkan 26 Oktober 2010 menujukkan bahwa Indonesia sebagai sebuah bangsa menghadapi berbagai ancaman yang berasal dari brbagai sumber, seperti $38,8 \%$ bersumber pada budaya korupsi, $15,1 \%$ karena faktor krisis ekonomi, 10,3\% faktor pengangguran, $9,7 \%$ karena faktor terorisme/ketidakamanan, 9,3\% masalah konflik antar kelompok, dan 5,6\% disebabkan birokrasi yang rusak. Laporan Transperancy International Indonesia diperkuat oleh laporan Fund for Peace and Foreign Policy Magazine yang menempatkan Indonesia pada peringkat 79 dari 178 negara sebagai negara terancam gagal (Wikipedia, http://www.id.wikipedia.org).

Kondisi objektif yang ada dan isu pendidikan yang dihadapi Indonesia mendorong pemerintah Republik Indonesia menetapkan kebijakan penerapan Kurikulum 2013. Sebagai suatu kebijakan baru, keberhasilan implementasi Kurikulum 2013 akan sangat dipengaruhi oleh banyak faktor. Salah satunya adalah masalah manajemen implementasi kurikulum. Penelitian Silver (2004:2) menemukan bahwa inisiatif dan kebijakan nasional dan terutama school policy management berpengaruh terhadap implementasi kurikulum di sekolah. Demikian juga hasil penelitian Bennie dan Newstead (1999:4) bahwa kendala-kendala implementasi kurikulum baru, terutama terkait dengan kekurangjelasan substansi isi kurikulum yang berimplikasi pada implementasi, kekurangsiapan guru, kondisi kemampuan siswa, dan budaya sekolah.

Penelitian Ratri dan Yuliana (2013) menunjukkan bahwa sosialisasi kurikulum, kemampuan guru, dan efektivitas kepala sekolah dalam memantau pelaksanaan kurikulum berpengaruh terhadap implementasi kurikulum. Ditambahkan oleh Lathifah (2013:1) bahwa implementasi kurikulum pada satuan pendidikan SMA Negeri Brebes kurang berhasil karena komunikasi yang kurang berjalan secara efektif dan efisien, sumber daya manusia kurang mendukung, isi kebijakan KTSP, dan lingkungan kebijakan yang kurang kondusif.

Berdasarkan diskusi tersebut, dapat dikaji beberapa aspek penting dalam penguatan manajemen implementasi Kurikulum 2013. Aspekaspek tersebut mencakup: (1) hakikat dan urgensi manajemen implementasi kurikulum sebagai landasan dalam pengimplementasian kurikulum 2013; dan (2) strategi penguatan impelemntasi Kurikulum 2013 agar pelaksanaan Kurikulum 2013 dapat mencapai keberhasilan yang diharapkan.

\section{HAKIKAT DAN URGENSI MANAJEMEN IMPLEMENTASI KURIKULUM}

Manajemen merupakan salah satu masalah penting dalam implementasi kurikulum, terutama kurikulum baru. Masalah manajemen menjadi sangat penting karena implementasi kurikulum memiliki sejumlah komponen dan aspek-aspek, faktor, dan strategi yang perlu ditata dan dikelola secara baik sehingga tujuan kurikulum dapat dicapai. Implementasi kurikulum merupakan salah satu bagian penting dari manajemen kurikulum. English \& Larson (2013: 1) menggambarkan (Gambar 1) bahwa manajemen kurikulum merupakan upaya dari keseluruhan proses delivery tujuan dan isi kurikulum ke dalam praktik pembelajaran di sekolah. Implementasi merupakan bagian dari keseluruhan manajemen kurikulum yang mencakup pengembangan kurikulum (curriculum development), implementasi (implementation), umpan balik (feedback), evaluasi (evaluation), modifikasi (modification) dan konstruksi kurikulum (curriculum construction). Dengan demikian, posisi manajemen implementasi kurikulum sangat strategis dan terkait dengan komponen manajemen lainnya. 


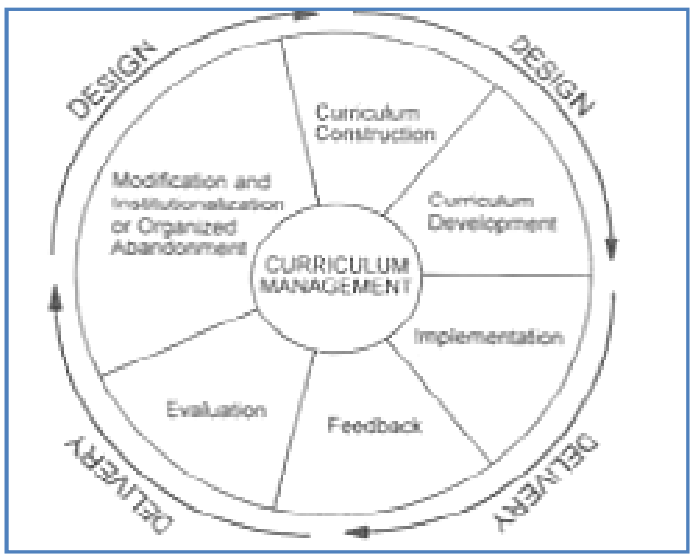

Gambar 1. Komponen Manajemen Kurikulum

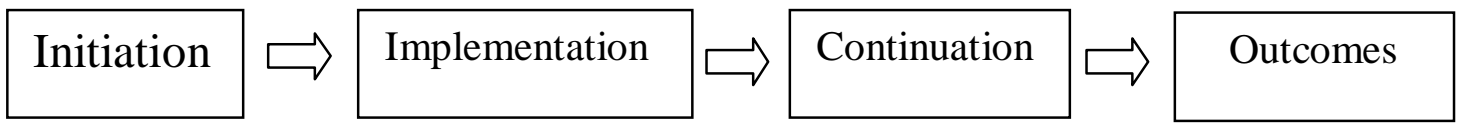

Gambar 2. Peran Implementasi dalam Proses Perubahan

Manajemen untuk implementasi kurikulum dapat diartikan sebagai suatu proses mengelola (managing) semua sumber daya pendidikan, baik individu, kelompok, maupun sumber daya lainnya yang memungkinkan terjadi proses delivery tujuan dan isi kurikulum ke dalam proses pembelajaran di sekolah. Implementasi kurikulum memerlukan suatu proses manajemen yang kuat dan baik. Implementasi kurikulum dapat dilihat sebagai suatu proses penerapan gagasan, ide, tujuan, dan keseluruhan program yang termuat di dalam suatu kurikulum. Setiap kurikulum termasuk kurikulum baru memiliki gagasan dan ide yang tercermin dalam tujuan, program, dan pendekatan dalam proses pembelajaran maupun dalam sistem evaluasinya. Dalam kaitan dengan gagasan-gagasan baru dari setiap kurikulum baru, Herbert Altrichter, mengemukakannya sebagai berikut.

Consequently, a new curriculum may be described as an attempt to change teaching and learning practices which will also include the transformation of some of the beliefs and understandings hitherto existent in the setting to be changed. It is usually strong on the material side by providing a written curriculum, text books, recommendationsfor teaching strategies, working material for students, and probably also new artifacts for learning (Heibert, 2005:35-62)
Berasarkan yang dikemukakan Herbert tersebut, tampak bahwa setiap kurikulum baru membawa konsekuensi yang digambarkan sebagai suatu perubahan. Perubahan-perubahan itu terutama terjadi pada tataran praktik pembelajaran, yang menjadi bagian dari suatu proses pembaharuan. Implikasinya adalah diperlukan suatu dukungan kebijakan, serta ketersediaan buku-buku dan bahan bacaan, strategi pembelajaran, serta berbagai perangkat dan media pembelajaran.

Implementasi kurikulum baru memerlukan suatu proses manajemen yang memungkinkan berbagai gagasan, ide yang terkadung di dalam perubahan suatu kurikulum dalam tercapai. Herbert menggambarkan posisi strategis implementasi dalam konteks suatu inovasi dan pembaharuan dapat dilihat pada Gambar 2 .

Berdasarkan Gambaran 2 yang dikemukakan oleh Herbert tersebut, implementasi ditempatkan sebagai suatu jembatan atau sebagai suatu proses yang menjamin kesinambungan berbagai gagasan, ide, dan tujuan yang terkandung dalam suatu proses inisiasi untuk mencapai tujuan atau dampak yang diharapkan. Pandangan implementasi kurikulum sebagai alat dapat dilihat juga dalam definisi yang dikemukakan oleh Beauchamp, "Implementation is a point of departure for teaching... and repre- 
sent $(s)$ the merger of the curriculum system with the instructional system; Tyler (1975) implementation is the operationalization of a curriculum plan, dan Paul, (1976) ... implementation as a cognitive process whereby potential adopters are made aware of an innovation (Daniel Common, 1978: 6).

Berdasarkan berbagai definisi tentang implementasi kurikulum di atas, dapat disimpulkan bahwa implementasi dapat dilihat dalam dua perspektif, yaitu implementasi sebagai instrumen dan implementasi sebagai suatu proses. Sekalipun keduanya dapat dilihat dalam perspektif yang berbeda, namun keduanya tidak dapat dipisahkan. Sebagai instrumen, implementasi mempunyai peranan penting untuk mewujudkan gagasan-gagagasan, ide dan ataupun tujuan kurikulum itu sendiri. Implementasi itu sendiri berlangsung dalam suatu proses, terutama proses pembelajaran. Oleh sebab itu, implementasi kurikulum sebagai suatu proses perlu dipahami sebagai upaya pengimplementasian tujuan kurikulum ke dalam proses pembelajaran. Oleh karena itu, sebaik apapun kurikulum itu dirancang, ia tidak akan terwujud dalam proses pembelajaran bila tidak didukung oleh manajemen implementasi yang memadai. Penelitian yang dilakukan oleh Labane (2009:4) menegaskan bahwa management of curriculum implementation plans as crucial to ensuring successful implementation of a new curriculum.

Faktor-faktor implementasi kurikulum merupakan kondisi yang akan mempengaruhi keberhasilan implementasi kurikulum. Karenanya, kondisi tersebut perlu mendapatkan perhatian dalam manajemen implementasi kurikulum. Faktor-faktor tersebut dapat dilihat pada Gambar 3 .

\section{Faktor Perencanaan Implementasi Kuriku- lum}

Perencanaan merupakan faktor strategis dalam implementasi suatu kurikulum, terutama kurikulum baru. Implementasi kurikulum terkait dengan banyak faktor yang harus dipersiapkan agar implementasi berhasil dengan baik. Perencanaan implementasi penting sebagai kerangka acuan sehingga terjadi efisiensi dalam pendaya- gunaan semua sumber daya, baik sarana prasarana maupun sumber daya manusia. Perencanaan dapat menjadi instrument penting untuk evaluasi program sejauh mana tujuan dan sasaran implementasi kurikulum dapat dicapai. Labane (2009:5) mengemukakan, "Curriculum implementation plans are required to assist the implementers to obtain a common understandding of the required curriculum practice. These plans become devices for identifying ways of solving or minimising problems related to implementation. Di dalam implementasinya, setiap kurikulum, terutama kurikulum baru akan menghadapi banyak masalah. Perencanaan akan membantu mengidentifikasi cara-cara mengatasi masalah dan sekaligus membantu mengurangi masala-masalah yang akan muncul di dalam implementasi kurikulum.

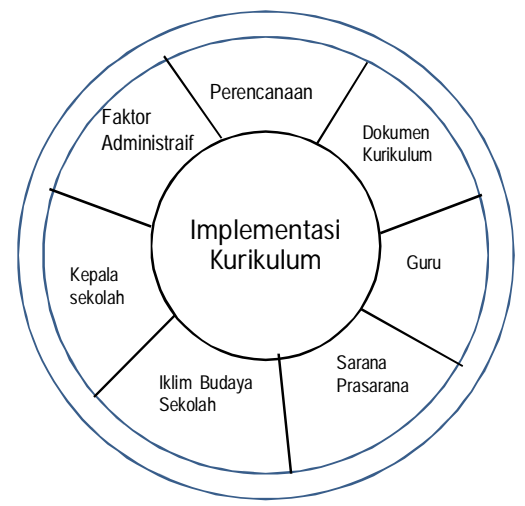

\section{Gambar 3. Faktor dalam Implementasi Kurikulum}

Perencanaan implementasi kurikulum penting untuk memberi arah implementasi. Implementasi kurikulum membutuhkan perencanaan yang baik dan jelas mengenai bagaimana organisasi dan mekanisme implementasi, tahapantahapan implementasi, kegiatan apa yang harus dilakukan dalam setiap tahapan itu, kapan waktu pelaksanaannya, siapa yang harus bertanggung jawab setiap tahapan dan setiap kegiatan, kebutuhan logistik apa yang diperlukan, serta berapa daya dan biaya yang diperlukan. Fullan seperti dikutip oleh Labane mengemukakan bahwa karakteristik implementasi kurikulum yang baik mencakup kejelasan mengenai how implementers should do the tasks, why they need to do 
these tasks, who must take responsibility for particular tasks, by whom such people will be supervised, and what kind of resources will be required (Labane, 2009:6). Kejelasan dalam perencanaan terhadap setiap aspek-aspek implementasi kurikulum tersebut akan memberi kepastian bahwa implementasi kurikulum akan berjalan dengan baik. Faleni (2005:13-14) mengemukakan urgensi perencanaan implementasi kurikulum baru terkait dengan beberapa kepentingan sebagai (1) identify opportunities and threats; (2) formulate objectives; (3) make assumptions and draw up plans of action accordingly; (4) identify alternative plans of action; (5) analyze and consider alternative plans of action; (6) choose a final plan; (7) draw up a budget; and (8) implement the plan.

Kurikulum baru memiliki karakteristik baru sehingga sangat diperlukan perencanaan implementasi yang baik. Melalui perencanaan, akan dapat diantisipasi berbagai tantangan serta peluang termasuk potensi yang dimiliki. Tujuan implementasi kurikulum itu sendiri harus jelas bagi semua pihak yang terkait, terutama guru dan kepala sekolah di tingkat mikro. Asumsiasumsi yang dibangun yang menjadi landasan bagi implementasi seperti diasumsikan bahwa semua sekolah menerima kurikulum baru. Melalui perencanaan, penting untuk dibuatkan alternatif strategi implementasi sampai pada tindakan implementasi itu sendiri. Suatu perencanaan implementasi kurikulum baru yang baik, hendaknya memuat aspek-aspek penting tersebut.

\section{Faktor Kurikulum}

Faktor kurikulum merupakan faktor yang berpengaruh terhadap implementasi kurikulum itu sendiri. Faktor-faktor tersebut dapat mencakup karaketirstik kurikulum seperti berikut. (1) Apakah memiliki kejelasan, baik tujuan, pendekatan, dan ataupun tata kelolanya. Kejelasan ini menjadi sangat penting agar tidak terjadi multitafsir mengenai tujuan, struktur, isi, pendekatan, dan sistem penilaian kurikulum itu sendiri. (2) Realistik dan relevan sehingga memperkuat kontekstualitas implementasinya. Kurikulum yang realistik dan relevan memberi ruang bagi guru-guru untuk mengembangkan bahan ajar yang relevan dan kontekstual dengan kehidupan anak dan lingkungannya. (3) Kerangka konseptual yang mendasari pengembangan kerangka isi konseptual bahan ajar. Altrichter (2005:1) menyebutkan conceptual matters sebagai salah satu limiting factors dalam implementasi kurikulum.

Bennie \& Newstead (1999:3) mengemukakan beberapa faktor kurikulum seperti (1) errors in the construction of the document; (2) content errors, and (3) in appropriate content. Faktor pertama adalah kelemahan dalam konstruksi kurikulum, baik perencanaan maupun pengembangannya. Evaluasi terhadap kurikulum lama, kajian dan analisis terhadap kerangka konseptual dan kontekstual kurikulum baru, serta keterlibatan berbagai pihak termasuk keterlibatan pengguna kurikulum sangat penting untuk memperkuat konstruksi kurikulum baru. Faktor kedua adalah kesalahan dalam hal isi kurikulum. Kesalahan isi kurikulum terutama dilihat dari relevansi dan kontektualitas isi kurikulum. Kesalahan pada isi kurikulum dapat menyebabkan anak menerima materi yang tidak standar dan akan berimplikasi pada kemampuan anak untuk kompetitif. Faktor ketiga adalah kesesuaian isi kurikulum, terutama dilihat dari aspek psikologis, yaitu kesesuaian dengan tingkat perkembangan inteligensi, sosial, dan moral anak. Artinya, sikuens bahan ajar sudah harus memperhatikan kesesuaiannya dengan perkembangan kemampuan-kemampuan psikologis anak.

\section{Faktor Guru dalam Implementasi Kuriku- lum}

Guru mempunyai peranan yang penting dalam implementasi kurikulum. Peran guru tersebut terutama dalam menjadikan kurikulum sebagai sesuatu yang aktual (actual curriculum) dalam kegiatan pembelajaran. Altirchter (2005: 9) menyebutkan tiga faktor penting dari guru sebagai faktor-faktor yang membatasi implementasi kurikulum, yaitu (1) competencies and attitude; (2) decision-making participation; and (3) quality of collegial relationship. Ketiga faktor yang dikemukakan Altirchter tersebut menunjuk pada kompetensi, baik kompetensi profesional, kompetensi pedagogik, kompetensi ke- 
pribadian maupun kompetensi sosial. Partisipasi dalam pengambilan keputusan menunjuk pada kemampuan partisipatif guru dalam pengambilan keputusan, baik pengembangan kurikulum maupun pembelajaran. Demikian juga dengan kualitas hubungan kolegial di sekolah dengan sesama guru. Kualitas hubungan kolegial tersebut penting untuk memperkuat kemampuan parsisipatif guru.

Bennie \& Newstead (2005:4) menyebutkan bahwa teachers' content knowledge merupakan salah satu faktor rintangan dalam implementasi kurikulum baru. Melalui penelitian yang mereka lakukan, ditemukan bahwa teacher content knowledge does influence classroom instruction and the richness of learners' mathematical experiences. Hasil penelitian ini memperkuat proposisi mengenai peran pengetahuan konseptual guru yang melandasi bahan ajar. Guru sudah harus memiliki pengetahuan konseptual yang kuat, baik konten bidang studi maupun pengetahuan konseptual pedogogik dan pembelajaran. Penguasan konten pedagogik dan keilmuan bidang studi akan memperkuat kemampuan guru dalam mengembangkan silabus, bahan ajar, dan pendekatan-pendekatan metodologis pembelajaran.

Pengembangan kemampuan guru untuk implementasi kurikulum baru memerlukan suatu manajemen kuat dan baik yang mencakup pengembangan kompetensi, baik kompetensi profesional, pedagogik, kepribadian maupun sosial. Terdapat beberapa aspek yang memerlukan tata kelola atau manajemen yang baik, yaitu perencanaan dalam pembinaan dan pengembangan kompetensi, pemanfaatan dan pendayagunaan, monitoring dan evaluasi, serta manajemen sistem pendukung baik regulasi, sarana dan prasarana, maupun dukungan finansial.

\section{Faktor Sarana dan Prasarana}

Sarana dan prasarana menjadi salah satu faktor yang mempunyai peranan penting dalam implementasi kurikulum. Terdapat sarana dan prasarana utama yang sangat diperlukan dalam implementasi kurikulum baru, yang terdiri atas hal-hal berikut.
Buku pelajaran. Perubahan kurikulum dan pemberlakukan kurikulum baru akan berimplikasi pada perubahan materi dan isi kurikulum. Hal ini berarti diperlukan buku untuk bahan ajar yang baru. Manajemen perbukuan dalam rangka implementasi kurikulum baru akan mencakup (1) penentuan jenis, bentuk, dan isi bahan buku; (2) pengadaan buku; (3) distribusi buku; dan (4) evaluasi dan umpan balik.

Laboratorium peralatan dan bahan. Peralatan dan bahan sudah harus tersedia dalam rasio yang mencukupi dan yang memenuhi standar mutu minimal laboratorium. Ketersediaan berbagai media pembelajaran baik jenis, bentuk maupun model. Media-media pembelajaran tersebut dapat terdiri atas dari media cetak, elektronik, maupun media berbasis lingkungan sekolah. Aksesibilitas penggunaan sarana dan prasarana oleh siswa dan guru. Ketersediaan sarana dan prasarana sudah harus diikuti dengan manajemen yang memungkinkan semua siswa dan juga guru-guru dapat dengan mudah mengakses ataupun memanfaatkan media yang tersedia.

Pemeliharaan, perawatan, dan pengembangan sarana dan prasarana. Sarana dan prasarana yang tersedia memerlukan perawatan, pemeliharaan, dan pengembangan sehingga dapat dijamin ketersediaan sarana dan prasarana tersebut secara berkelanjutan. Buku dan bahan ajar memerlukan peninjauan kembali setiap tahun ajaran. Laboratorium baik peralatan maupun bahan sudah harus dijamin selalui tersedia dalam keadaan baik dan bermutu. Berbagai media pembelajaran yang ada memerlukan perawatan dan perbaikan sehingga selalu siap dan dapat digunakan.

\section{Faktor Iklim dan Budaya Sekolah}

Setiap kurikulum baru memuat banyak hal yang baru. Inovasi-inovasi baru dapat mencakup tema-tema yang diusung, tata kelola, pendekatan dalam proses pembelajaran, muatan dan isi kurikulum, dan atau sistem penilaian. Inovasi dan hal-hal baru tersebut membutuhkan perubahan dalam pola pikir, sikap, dan juga iklim serta budaya sekolah. Guru yang dalam tugas kesehariannya terjebak dalam praktik pembelajaran yang rote learning membutuhkan perubah- 
an mind set atau perubahan cara berpikir dan sikap terhadap pendekatan pembelajaran yang ilmiah (scientific approach) yang sangat mengedepankan aktivitas belajar secara ilmiah seperti mengamati, menanya, mencoba, menganalisis, menyimpulkan, dan atau mengevaluasi.

Iklim sekolah sudah harus diciptakan dan dibangun sehingga memberi ruang terbentuknya sikap dan perilaku ilmiah dalam proses pembelajaran. Bennie \& Newstead mengemukakan bahwa school culture sebagai salah satu faktor yang dapat merintangi implementasi berbagai inovasi kurikulum baru. Dengan merujuk hasil penelitian Nickson yang dilakukan di beberapa sekolah di Afrika Selatan, Kate dan Karen (2005:7) mengutip hasil tersebut sebagai berikut. "... This suggests that the existing culture in South African schools is going to have an important influence on the implementation of Curriculum 2005." Berdasarkan kesimpulan hasil penelitian tersebut, tampak bahwa budaya sekolah mempunyai pengaruh yang sangat penting dalam implementasi kurikulum.

Guru mempunyai peran yang penting dalam membangun dan menciptakan budaya sekolah yang kondusif. Dalam konteks ini adalah implementasi berbagai inovasi di dalam pelaksanaan kurikulum baru. Peran itu dapat dilakukan melalui perubahan cara berpikir, sikap, dan perilaku yang nampak dalam kegiatan-kegiatan pembelajaran yang dikembangkan guru. Guru dapat memulai perubahan itu melalui proses pembelajaran, dari pendekatan pembelajaran yang rote learning ke pembelajaran meaningfull learning. Melalui proses pembelajaran, siswa dilatih dan dibiasakan untuk melakukan langkah-langkah ilmiah, seperti mengamati, menanya, mencoba, menganalisis, mengkonstruksi idea atau fakta, menarik konklusi, serta melakukan evaluasi kritis. Budaya belajar seperti ini akan menjadi budaya sekolah, yaitu ketika terjadi proses institusionalisasi nilai-nilai ilmiah sehingga menjadi nilai lembaga.

\section{Faktor Peran Kepala Sekolah}

Kepala sekolah mengemban fungsi manajerial dalam implementasi kurikulum. Fungsi manajerial tersebut mencakup fungsi perencanaan, pelaksanaan, monitoring, dan evaluasi, serta fungsi pengembangan. Dimba (2001:60-62) melalui hasil penelitiannya mengemukakan lima aspek penting dari peran kepala sekolah dalam implementasi kurikulum. (1) Kemampuan kepala sekolah dalam mengorganisir kegiatan pengembangan, seperti inservice training programmes, workshop, staff development meetings and by inviting experts. (2) Mengembangkan strategi implementasi yang beragam untuk membimbing guru. (3) Melakukan kolaborasi dengan pengguna (stakeholders) dalam menata kelola perubahan kurikulum. (4) Melibatkan stakeholders dalam manajemen implementasi. (5) Melibatkan orang tua dalam implementasi.

Lingkup peran kepala sekolah seperti yang dikemukakan Dimba tersebut mengimplikasikan beberapa hal penting mengenai peran kepala sekolah dalam memperkuat manajemen implementasi kurikulum. Pertama, peran perencanaan mengenai implementasi dan pengembangan sumber daya. Kedua, faktor kemampuan mengembangkan strategi implementasi melalui penyiapan dan pembimbingan guru. Ketiga peran kolaboratif, yaitu manajemen dalam mengembangkan kerjasama, baik dengan stakeholder maupun orang tua murid.

Dalam konteks peran kepala sekolah dan tim manajemen di sekolah, Altrichter (2005:9) mengemukakan sejumlah faktor keberhasilan dalam implementasi kurikulum, yaitu (1) level of commitment; (2) obtaining resources; (3) encouraging staff/ recognition; and (4) adapting standard procedures. Kepala sekolah bersama tim manajemen dan guru membutuhkan komitmen yang kuat untuk melaksanakan berbagai inovasi dan terobosan-terobosan baru, yang membutuhkan perubahan dalam pola pikir, sikap, dan perilaku. Keterbatasan sumber daya untuk implementasi kurikulum membutuhkan kemampuan manajemen kepala sekolah untuk mempersiapkan, mengembangkan, dan mendayagunakan semua potensi sumber daya yang tersedia. Manajemen kepala sekolah harus mampu mendorong dan memotivasi guru dan staf serta elemen yang terlibat dalam implementasi kurikulum. Terpenuhinya prosedur standar implementasi menjadi 
salah satu indikator ketercapaian dan keberhasilan implementasi.

\section{STRATEGI PENGUATAN IMPLEMENTA- SI KURIKULUM 2013}

Agar implementasi Kurikulum 2013 dapat berhasil seperti yang diharapkan oleh pemerintah dan memenuhi harapan masyarakat, implementasi Kurikulum 2013 perlu didukung oleh strategi penguatan sebagai berikut.

\section{Rencana Implementasi Kurikulum 2013}

Dalam rangka implementasi kurikulum 2013, Kementerian Pendidikan dan Kebudayaan telah memiliki rencana implementasi. Rencana implementasi tersebut mencakup tiga kegiatan utama, yaitu penyediaan atau pengadaan buku, penyediaan sumber daya manusia, terutama guru, dan kegiatan monitoring dan evaluasi. Pengadaan buku terdiri dari kegiatan-kegiatan penulisan buku ajar, penyiapan buku master, dan pengadaan buku. Penyediaan sumber daya manusia dilakukan dengan sasaran guru, kepala sekolah, dan pengawas (Kemdikbud, Pengembangan Kurikulum 2013, Paparan Menteri Pendidikan dan Kebudayaan, Bandung, 16 Maret 2013).
Penyiapan guru dilakukan dalam tiga kategori yang terdiri dari instruktur nasional, guru inti, dan guru sasaran. Skema kerja pelatihan bagi guru didesain sebagai berikut (Kemendikbud RI Peran Guru dalam Implementasi Kurikulum 2013).

Skema kerja pelatihan pada Gambar 4 menunjukkan kegiatan pelatihan yang berjenjang. Pada tingkat pertama, dilatih dan disiapkan instruktur nasional. Kemudian, mereka akan menjadi instruktur pada pelatihan guru, kepala sekolah, dan pengawas serta guru inti untuk setiap provinsi. Guru, kepala sekolah, pengawas, dan guru inti yang telah lulus difungsikan untuk menjadi instruktur bagi guru, kepala sekolah, dan pengawas di setiap lokasi (kabupaten dan atau kota). Terobosan lain yang dilakukan oleh Kementerian Pendidikan dan Kebudayaan ialah pelatihan guru-guru yang dilaksanakan terintegrasi dengan kegiatan Pendidikan dan Latihan Profesi Guru (PLPG). Sebagaimana diketahui bahwa Kurikulum 2013 menjadi materi utama PLPG 2013. Di samping informasi tentang $\mathrm{Ku}-$ rikulum 2013, semua kegiatan pendalaman materi, pengembangan model-model pembelajaran, penelitian tindakan kelas, dan workshop diarahkan untuk implementasi Kurikulum 2013.

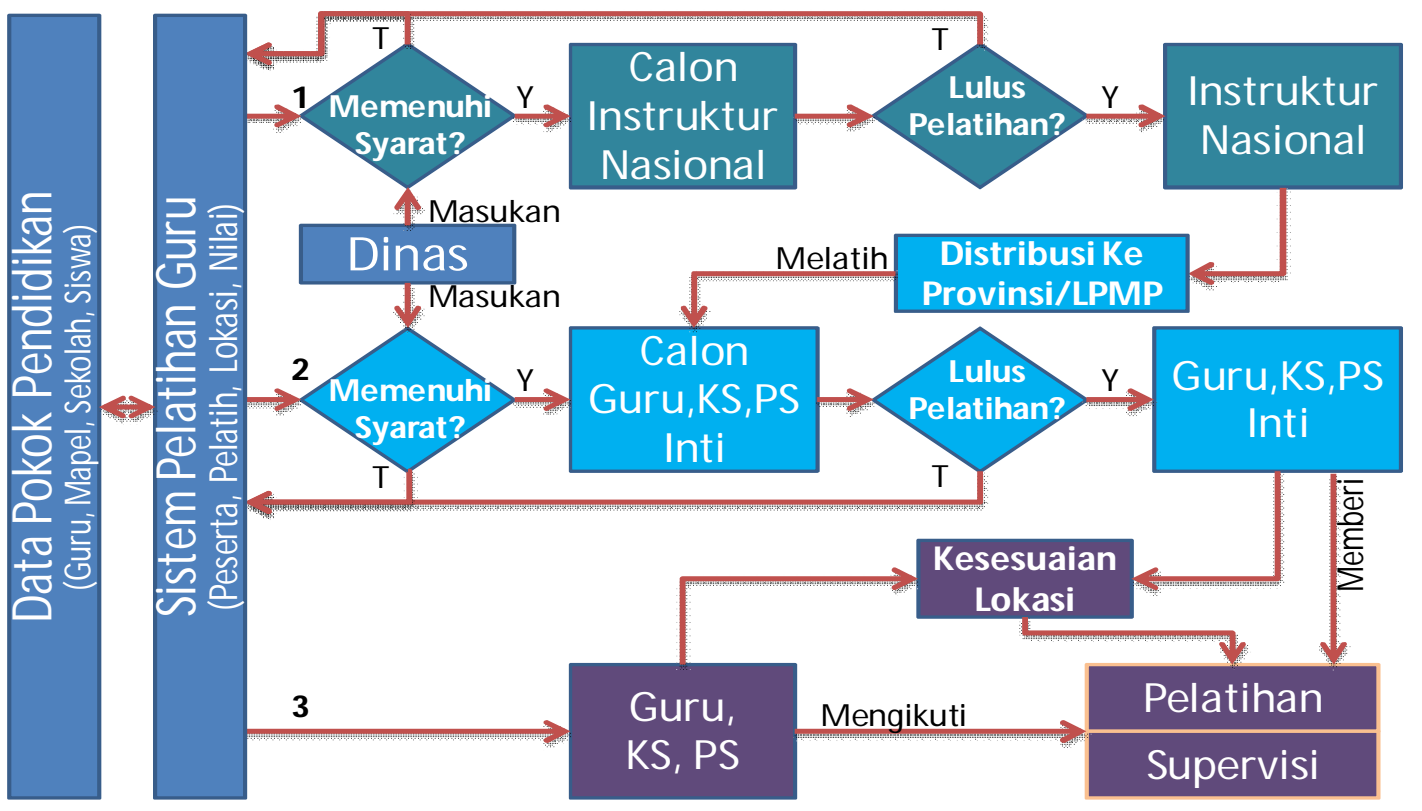

Gambar 4. Skema Kerja Pelatihan Guru 


\section{Strategi Penguatan Implementasi Kurikulum 2013}

Setelah memahami rencana impelemtasi Kurikulum 2013, langkah selanjut adalah menyusun strategi penguatan implementasi Kurikulum 2013. Strategi penguatan meliputi perencanaan implementasi, sumber daya manusia, pembelajaran, serta monitoring dan evaluasi.

\section{Perencanaan Implementasi}

Setelah mencermati perencaaan implementasi Kurikulum 2013 yang disiapkan oleh Kementerian Pendidikan dan Kebudayaan, dapat dikemukakan beberapa hal untuk penguatan rencana implementasi. Pertama, perencanaan yang komprehensif atas semua komponen dan aspek implementasi suatu kurikulum, terutama kurikulum baru. Komprehensitas aspek dalam perencanaan implementasi kurikulum mencakup hal-hal berikut.

- Ketersediaan dokumen kurikulum dan kelengkapan instrumentasinya. Ketersediaan dokumen untuk dimiliki oleh setiap sekolah, pengawas, dan guru ditujukan untuk membantu dan memperkuat pengenalan dan pemahaman tentang kurikulum yang baru. Ketersediaan dokumen akan menjadi indikator mutu manajemen implementasi kurikulum. Selain itu, juga membantu keterlaksanaan kurikulum secara efektif. Ketersediaan dokumen kurikulum perlu dilengkapi dengan ketersediaan kelengkapan instrumen yang terdiri atas peraturan pelaksanaan, panduan, dan prosedur operasi standar (POS). Untuk mendukung keterlaksanaan implementasi, telah dikeluarkan sejumlah Peraturan Menteri Pendidikan dan Kebudayaan tahun 2013.

- Perencanaan sosialisasi. Penerimaan suatu ide dan ataupun gagasan baru tergantung pada pemahaman terhadap ide dan atau gagasan baru tersebut. Terdapat dua aspek sosialisasi yang perlu dilakukan dalam rangka penguatan implementasi kurikulum 2013, yaitu pemanfaatan berbagai media untuk sosialisasi, dan tingkat pemahaman tentang tema utama, ruang lingkup, pendekatan pembelajaran di samping struktur, isi, dan sistem penilaian- nya. Media sosialisasi dapat dilakukan baik melalui media cetak, elektronik, dan atau sosialisasi secara langsung. Sementara itu, tingkat pemahaman tentang kurikulum dapat dilihat dari sikap dan perilaku menerima, merespon, melaksanakan, dan bahkan melakukan evaluasi kritis.

- Perencanaan sistem pendukung, baik sarana prasarana maupun sumber daya, yaitu sumber daya manusia dan sumber daya finansial. Diperlukan kajian dan evaluasi yang cermat mengenai kebutuhan sarana dan prasarana serta sumber daya yang dibutuhkan. Kajian dan evaluasi tersebut mencakup rasio ketersediaan dan ketercukupan, mutu, dan kemampuan sekolah untuk perawatan dan keberlanjutan. Terdapat beberapa kebutuhan strategis yang sangat diperlukan dalam implementasi Kurikulum 2013, yaitu (1) buku pelajaran harus memenuhi persyaratan relevansi dan kemutakiran di samping rasio ketersediaan dan mutu; (2) laboratorium baik peralatan maupun bahan; dan (3) perencanaan untuk kebutuhan dan pengembangan media pembelajaran, serta perencanaan sumber daya finansial.

- Perencanaan tahapan waktu pelaksanaan, serta keterlibatan stakeholders. Tahapan-tahapan implementasi yang baik hendaknya mencakup rentang waktu pelaksanaan kegiatan, penanggung jawab setiap kegiatan, serta keterlibatan pihak-pihak terkait. Pemerintah melalui Kementerian Pendidikan dan Kebudayaan telah menyiapkan rencana persiapan implementasi dan rencana implementasinya. Untuk rencana implementasi disusun tahapan waktu, yaitu tahun 2013 sampai dengan tahun 2015. Diawali dengan implementasi terbatas, dan secara bertahap implementasi secara keseluruhan sampai dengan tahun 2015. Implementasi dilakukan secara bertahap, yaitu untuk sekolah dasar hanya 10\% dari seluruh sekolah dengan dua kelas (kelas I dan kelas IV), SMP/MTs kelas VII, dan SMA/MA/ SMK kelas X. Kelas lainnya secara bertahap akan dilaksanakan tahun 2014 dan 2015, (Sumber: Paparan Mendikbud, Bandung 16 Maret 2013). 
Tabel 1. Tahapan Pelaksanaan Kurikulum 2013

\begin{tabular}{ccccc}
\hline \multirow{2}{*}{ No } & \multirow{2}{*}{ Jenjang Satuan } & Kelas & Tahun \\
\cline { 4 - 5 } 1. & SD & I & 2013 & 2014 \\
& & II & & \\
& & III & & \\
& & IV & & \\
2. & SMP & V & & \\
& & VII & & \\
3. & SMA/SMK & VIII & & \\
& & IX & & \\
\end{tabular}

SD: $30 \%$ dari populasi kelas I dan IV (10\% dari populasi SD)

SMP, SMA/SMK: 100\% dari populasi kelas VII dan X (30\% dari populasi SMP, SMA/SMK)

\section{Penguatan Sumber Daya Utama dan Pendu- kung}

Terdapat dua sumber daya yang harus menjadi perhatian dalam implementasi Kurikulum 2013, yaitu sumber daya utama dan sumber daya pendukung. Sumber daya utama terdiri atas sumber daya manusia dan bahan ajar. Guru adalah faktor utama yang akan mengimplementasikan kurikulum. Berkaitan dengan hal tersebut, seorang guru perlu mempersiapkan hal-hal seperti berikut.

- Kompetensi dan sikap. Kompetensi dapat terdiri atas kompetensi pedagogik, yaitu penguatan kompetensi guru mengenai landasan-landasan pedagogik Kurikulum 2013; kompetensi profesional yaitu penguatan mengenai kompetensi baik kompetensi inti maupun kompetensi dasar, bahan ajar, pendekatan pembelajaran kurikulum 2013; sistem evaluasi dan tata kelola Kurikulum 2013.

- Pelibatan guru-guru dalam proses pengambilan keputusan implementasi kurikulum. Pelibatan ini pada tataran mikro dilakukan di tingkat sekolah dalam menyusun agenda kegiatan implementasi kurikulum di sekolah.

- Perlu dibangun dan dipersiapkan hubungan kolegial yang berkualitas di sekolah-sekolah. Implementasi kurikulum 2013 mensyaratkan perlunya hubungan kolegial yang kuat sehingga terjadi proses sharing sumber daya yang tersedia. Guru-guru yang sudah mengikuti pendidikan dan latihan mengenai kuri- kulum 2013 dapat menjadi nara sumber dan sejawat sebagai mitra dalam impelembtasi kurikulum.

Di samping guru, yang perlu dipersiapkan ialah kepala sekolah sebagai manajer di sekolah. Fungsi manajemen kepala sekolah baik untuk merencanakan, melaksanakan, mengawasi dan mengevaluasi pelaksanaan implementasi sangat penting. Berdasarkan berbagai hasil penelitian menunjukkan bahwa kepala sekolah memunyai peranan yang sangat penting dalam implementasi kurikulum. Berbagai hasil penelitian tersebut menunjukkan setidaknya terdapat lima kemampuan yang harus dipersiapkan dari seorang kepala sekolah seperti berikut (Dimba, 2001:6062).

- Kemampuan kepala sekolah untuk mengorganisir kegiatan pengembangan seperti inservice training programmes, workshop, staff development meetings and by inviting experts,

- Mengembangkan strategi implementasi yang beragam untuk membimbing guru.

- Melakukan kolaborasi dengan stakeholders dalam menata kelola perubahan kurikulum.

- Melibatkan stakeholders dalam manajemen implementasi.

- Melibatkan orang tua dalam implementasi.

Sekolah melalui kepala sekolah sudah harus memiliki program implementasi dan pengembangan Kurikulum 2013. Program tersebut dapat mencakup tahapan persiapan, rencana penyiapan dan pengembangan guru-guru melalui 
kegiatan-kegiatan seperti seminar, workshop, atau kegiatan kerjasama guru antarsekolah dan atau antarmata pelajaran. Rencana kerjasama dengan berbagai pihak baik pemerintah daerah, perguruan tinggi, antarsekolah, dan stakeholders lainnya perlu dikembangkn oleh kepala sekolah. Orang tua sebagai stakeholders utama perlu didorong keterlibatannya melalui kegiatan-kegiatan terorganisir oleh lembaga-lembaga seperti komite sekolah atau lembaga sejenis lainnya.

Penguatan sumber daya pendukung, terutama ketersediaan sarana yang mendukung fasilitas pembelajaran, yaitu buku sebagai bahan ajar. Pemerintah telah menyiapkan buku pelajaran terutama buku pelajaran untuk sekolah dasar (SD). Buku pelajaran untuk semua tema pelajaran sudah dipersiapkan. Di samping itu, telah dipersiapkan pula buku pedoman bagi guruguru. Penyiapan buku bahan ajar hendaknya tetap memerhatikan prinsip-prinsip relevansi dengan kehidupan anak. Buku hendaknya dirancang untuk dapat mendorong inspirasi guru dalam mengembangkan bahan ajar yang relevan dengan menghubungkan lingkungan terdekat sebagai sumber belajar.

Sumber daya pendukung untuk implementasi Kurikulum 2013 terutama adalah ketersediaan sarana pembelajaran, baik dalam jumlah maupun mutu. Implementasi kurikulum membutuhkan ketersediaan laboratorium, baik peralatan maupun bahan. Perlu disadari bahwa masih banyak sekolah yang memiliki fasilitas standar minimal. Seiring dengan implementasi kurikulum yang dilakukan secara bertahap sampai dengan tahun 2015, diperlukan komitmen tentang kebijakan untuk mempersiapkan sarana dan fasilitas pembelajaran utama. Komitmen kebijakan tersebut terutama harus datang dari setiap pemerintah daerah.

\section{Penguatan Pembelajaran di Sekolah}

Implementasi kurikulum secara aktual terjadi dalam proses pembelajaran. Beberapa aspek yang perlu diperkuat dalam pembelajaran di sekolah antara lain seperti berikut.

- Ketersediaan perangkat pembelajaran yang bermutu, terutama Rencana Pelaksanaan Pembelajaran (RPP). Pengalaman empirik dari ber- bagai penilaian terhadap RPP guru, baik melalui kegiatan pemeriksaan portofolio maupun Pendidikan dan Latihan Profesi Guru (PLPG) ditemukan kelemahan-kelemahan mendasar dalam menyiapkan RPP. Kelemahan-kelemahan tersebut antara lain kemampuan guru dalam membuat jaringan tema, sekalipun kompetensi dasar telah tersedia.

- Kemampuan guru dalam mengembangkan strategi pembelajaran dapat dipersiapkan dalam dua hal, yaitu pengetahuan mereka tentang berbagai pendekatan, model dan strategi pembelajaran inovatif sebagaimana dikehendaki oleh Kurikulum 2013, serta kemampuan guru untuk menerapkannya.

- Kemampuan guru dalam mengembangkan dan melakukan proses penilaian. Guru-guru masih perlu dipersiapkan baik pengetahuan maupun keterampilan untuk menerapkan penilaian otentik (authentic assessment) dalam proses pembelajaran Kurikulum 2013. Sekalipun penilaian otentik sudah dikenal lama, pelaksanaan penilaian otentik secara sistematik memerlukan kesiapan dan kemampuan guru untuk dapat menerapkan sehingga dapat dicapai tujuan diterapkannya penilaian otentik tersebut.

Di samping faktor instrumental dan sumber daya guru yang harus disiapkan untuk mendukung keterlaksanaan proses pembelajaran di sekolah, aspek lain yang harus dikembangkan adalah iklim sekolah. Iklim sekolah dilakukan dengan mengembangkan nilai-nilai yang harus menjadi norma lembaga, seperti budaya disiplin, jujur, menjunjung tinggi kebenaran, objektif, bertanggung jawab, bersih, etos kerja tinggi, dan kreativitas. Proses pelembagaan nilai-nilai tersebut dapat dilakukan dengan menyiapkan normanorma etika dan tata tertib sekolah. Kepala sekolah dan guru sudah harus menjadi pelaku utama nilai-nilai etika yang dikembangkan. Sosialisasi nilai-nilai etika dilakukan melalui berbagai media, baik tatap langsung ataupun media cetak dan media lainnya seperti kegiatan-jegiatan kurikuler dan ekstra kurikuler. Komitmen dari semua pihak yang terkait di sekolah seperti guru, siswa, kepala sekolah, dan tenaga kependidikan 
menjadi faktor yang juga ikut mendukung keterlaksanaan proses pembelajaran di sekolah.

\section{Penguatan Monitoring dan Evaluasi}

Penguatan montoring dan evaluasi penting untuk memperoleh umpan balik pelaksanaan kurikulum. Hambatan dan kesulitan-kesulitan yang dihadapi dalam rangka implementasi, solusi, dan strategi perbaikan dari hasil monitoring dan evaluasi akan menjadi materi umpan balik untuk penguatan implementasi. Monitoring dan evaluasi dilakukan, terutama pada pelaksanaan kurikulum di tingkat mikro, sekolah dan kelaskelas melalui kegiatan proses belajar mengajar. Umpan balik dalam rangka monitoring dilakukan terhadap guru, kepala sekolah, siswa, orang tua maupun pihak terkait, seperti dinas pendidikan dan atau komite sekolah.

\section{PENUTUP}

Keberhasilan implementasi kurikulum membutuhkan manajemen implementasi yang baik. Dalam rangka implementasi Kurikulum 2013, terdapat beberapa langkah penguatan yang perlu dilakukan sebagai strategi untuk menguatkan keberhasilan implementasi Kurikulum 2013. Strategi tersebut meliputi langkahlangkah penguatan perencanaan implementasi, sumber daya utama dan pendukung, proses pembelajaran di sekolah, dan kegiatan monitoring dan evaluasi. Guru, kepala sekolah, sarana dan prasarana, serta iklim atau budaya sekolah dan partisipasi semua pihak terkait sangat berperan dalam pencapaian keberhasilan implementasi kurikulum baru. Oleh karena itu, dibutuhkan strategi penguatan implementasi yang komprehensif dan integratif sehingga semua potensi dan sumber daya dapat dimanfaatkan. Ketersediaan dokumen dan berbagai instrumen sebagai kerangka acuan implementasi serta keterlaksanaan secara konsisten di lapangan penting untuk menjaga mutu dan keberhasilan implementasi. Monitoring dan evaluasi dilakukan dalam rangka penguatan partisipasi semua pihak terkait penting bagi perbaikan manajemen dan strategi penguatan implementasi.

Strategi yang baik akan berhasil bila didukung oleh keterlibatan dan komitmen oleh semua pihak yang terkait. Pengambil keputusan memunyai peranan strategis, baik keputusan-keputusan strategis maupun keputusan-keputusan operasional implementasi serta keputusan penting untuk mengatasi masalah-masalah di lapangan. Guru dan kepala sekolah memunyai peranan penting sebagai aktor utama dalam implementasi kurikulum. Demikianjuga dengan siswa, orang tua, dan pengguna, serta pihak terkait lainnya berkepentingan dalam fungsi montiroing dan evaluasi.

\section{UCAPAN TERIMA KASIH}

Ucapan terima kasih disampaikan kepada berbagai pihak yang telah membantu penulisan ini, baik secara langsung maupun tidak langsung. Semoga hal itu menjadi amal kebaikan yang bernilai pahala.

\section{DAFTAR PUSTAKA}

Altrichter, Herbert. 2005. "Curriculum Implementation-Limiting and Facilitating Factors, Johannes-Kepler-University", Published in Peter Nentwig and David Waddington (eds.): Context Based Learning of Science. Waxmann: Münster 2005, 35-62, www.c2c.oise.utoronto.ca, Diakses 21 Juni 2013.

Bennie, Kate and Karen Newstead. 1999. Obstacles to Implementation a New Curriculum. www.academic.sun.ac.za. Diakses 21 Juni 2013.

Dimba, Friedah Moko. 2001. The Role of Principals in Managing Curriculum Change, Department of Educational Planning and Administration University of Zululand, 2001. www. uzspace.uzulu.ac.za.

Faleni, Tutu Lawrence. 2005. "A Strategy for the Effective Management of the Implementation of the Revised National Curriculum Statement Grades R-9 (Schools) in the North-West Province, 2005", Dissertation, North-West University (Vaal Triangle Faculty) http dspace.nwu.ac.za, Diakses 23 Juni 2013. 
Schwab, Klaus. "The Global Competitiveness Report 2011-12". World Economic Forum.

http://www3.weforum.org/docs/WEF_ GCR_Report_2011-12.pdf. Diakses 26 September 2012.

Latifah, Eva. "Implementasi Kurikulum Tingkat Satuan Pendidikan di SMA Negeri Kabupaten Brebes". http//lonta rui.ac.id. Diakses 21 Juni 2013.

English, Fenwick W. and Robert L. Larson. Curriculum Management for Education and Social Service Organization. www. angelfire.com. Diakses 21 Juni 2013.

Kementerian Pendidikan dan Kebudayaan RI. Peran Guru dalam Implementasi Kurikulum 2013. www.info.disikporabna.com. Diakses 23 Juni 2013.

Kementerian Pendidikan dan Kebudayaan RI. Pengembangan Kurikulum 2013. www.upi.edu. Diakses 23 Juni 2013.
Labane, Nokubonga. 2009. Planning and Managing Curriculum Implementation in Rural Schools: an Investigation, Nelson Mandela Metropolitan University, www.dspace.nmmu.ac.za:8080. Diakses 21 Juni 2013.

Silver, Rita Elaine. 2004, Curriculum Implementation in Early Prymary Schooling in Singapore. www.nie.edu.sg. Diakses 21 Juni 2013.

Ratri, Safitri Yosita dan Yuliana, Lia. Implementasi Kurikulum Tingkat Satuan Pendidikan di SMA Negeri 10 Yogyakarta. www.staff.uny.ac.id. Diakses 23 Juni 2013.

Winataputra, Udin S. 2010. Kebijakan Nasional Pembangunan Karakter Bangsa melalui Pendidikan Karakter (Konsep, Kebijakan, dan Kerangka Programatik. Jakarta: Kementerian Koordinator Kesejahteraan RI. 